\title{
The effect of modifying spelling rules on the Orthography Education
}

\author{
Rasit Koc \\ Department of Turkish Education, YuzuncuYil University, Van, Turkey. \\ Received 24 December, 2013; Accepted 22 July, 2014
}

\begin{abstract}
The current study examined four different orthography guides prepared by Turkish Language Society between 1996 and 2012. These orthography guides included different spellings in words with capital letters, compound words, abbreviations, and some other words. The spelling differences defined were analyzed in groups. Different spelling preferences in abbreviations were presented in a table. The issues that these orthographic modifications may involve in Turkish language teaching were discussed. The orthography unity in words and abbreviations was emphasized and what to do in order to provide unity was put forward in conclusion and suggestions section.
\end{abstract}

Key words: Turkish Language Society (TLS), Turkish Language, orthography, grammar rules.

\section{INTRODUCTION}

One important element of native language teaching is the orthographic rules education. Orthographic rules guide us in writing and pronouncing words in our language accurately. An individual, beginning to learn the native language through random and aural acculturation since birth, acquires his/her mother tongue as it is spoken by the immediate surroundings and the family until school age. At the school age, s/he begins to become literate in written language through deliberate acculturation and learns the orthographic and punctuation rules. These rules help use the language more efficiently and accurately. As the individual learns the rules and punctuation marks that strengthen articulation, his/her skill to use the written expression improves. Thus, s/he is able to use the written and spoken language of culture.

Writing is the most difficultly and latest developing skill among the four language skills. Writing skills develop very slowly because it is attained through various exercises (Demirel, 1999: 72). It is required to know the syntax, tenses used, and the accurate usages of the words and affixes in written expression.

Orthographic education is to be considered and provided along with vocabulary learning because word meanings and spellings cannot be considered separately. A student is not thought to have gained a word so long as s/he cannot say and write it accurately and know its correct meaning. Inaccurate spelling, as well as inadequate expression, indicates that the individual is not welleducated, attentive, and does not respect his/her mother tongue. Therefore, the orthography is an important part of native language education (Göğüş, 1978: 371). Thus, in order to use the language accurately, it is required to know the grammar and orthographic rules in language education in general and in Turkish language teaching in

E-ma il: ra sitkoc @yyu.edu.tr Tel: 0905052542112

Author agree that this a ric le rema in pemanently open access under the terms of the $\underline{\text { Creative Commons }}$ Attribution License 4.0 Intemational Lic ense 
particular. Orthographic education is important in terms of developing writing skills. It is a priority for students to master the rules of standard Turkish and apply them in written expression of the language (Özbay, 2011: 181). Languages, in relation to the linguistic family that they belong to, possess sound features, pronunciation and writing methods and certain orthographic rules. Orthography of a language depends on the $F$ as well; particularly in our language, orthography is largely based on rules (Göğüş, 1978: 371). These rules historically develop and take form. Based on the changes experienced in languages, orthographic rules are naturally modified because language is alive and it always develops and evolves. New words and rules may be included in languages in different periods or some words and rules change or go extinct in time. This is a result of aliveness of the language.

Languages of the world are classified in groups of roots and forms and these groups make the linguistic families. Turkish language is structurally included in agglutinative languages family and it is a suffixing language. Based on the roots, it is considered within Ural Altaic language family. All languages within the Ural Altaic family have vocal harmony. There are some other writing rules governing the Turkish words or the words borrowed from other languages into Turkish, today. Anyone learning the native language is required to know and apply the rules of the language. Thus, the structure of the language is not broken and the individual's language usage skills will improve. Studies on Turkish orthography rules and their application, today, are conducted by Turkish Language Society (TLS). Orthography guides, dictionaries, and other publications on our language assist in defining and implementing Turkish orthographic rules. Turkish Language Society defines Turkish orthographic rules through the orthography guides that it publishes. It is observed that some different written forms and changes in spellings of some words, abbreviations, and phrases are included within the guides that the Society publishes at different times. We observe that even the names of guides that the Society publishes are affected by the changes. Guides prepared until 2005 were published as ImlâKılavuzu (Orthography Guide) whereas, in 2005 and beyond, they were changed into YazımKılavuzu (Orthography Guide). Undoubtedly, the reason for such change is that the Turkish translation of the Arabic imlâ (orthography) is yazım in Turkish. Turkish words, imlâ and yazım, are entered separately in Turkish dictionary and their correspondences are shown as follows:

imla is. (imlâ:) Ar. imlâ 1.Yazım.2.esk.Doldurma, doldurulma (TDK, 2005: 962).

(orthography, n. Arabic, 1. Orthography, 2.old usage, stuffing, being stuffed (TLS, 2005: 962)

yazım is. dbl. Birdilin belli kurallarlayazıyageçirilmesi, imla (TDK, 2005: 2155).

(orthography, $n$. grammar. Writing of a language in certain rules, orthography (TLS, 2005: 2155)
These changes directly affect the teaching of Turkish grammar and orthography at schools because the teachers of the related subjects are mostly not immediately informed of these modifications in orthography rules. Therefore, different applications in teaching orthography rules at schools are observed. Thus, instead of a common written form in language, different understandings of written form, depending on individuals and even institutions, occur and this negatively influences the written language. The current study investigates the modifications of orthographic rules found in orthography guides published by the Turkish Language Society and the reflections of these modifications on grammar and orthography teaching.

\section{METHODOLOGY}

The current study investigates the orthography guides published by the Turkish Language Society in and beyond 1996, through scanning method, and defines the modifications in orthography and rules.

\section{Purpose of the study}

The current study aims to define the orthography modifications in Turkish words and investigate the reasons for these modifications and the effects of the modifications on writing education.

\section{Population and sample}

The population of the study consists of the orthography guides published by the Turkish Language Society and the sample of the current study is limited to the orthography guides published by the Turkish Language Society in 1996, 2000, 2005 and 2012.

\section{FINDINGS AND DISCUSSION}

Modified orthographic rules within the orthographic guides published by the Turkish Language Society in 1996, 2000, 2005 and 2012 are as follows:

Modifications in writing the capital letters: "Poem lines that begin with capital letters" is included in orthography guides in 1996 and 2000 (TLS, 1996 and 2000: 24) whereas "poem lines that often begin with capital letters" (p.15) is included in the guide published in 2005. Two types of modifications attract attention in this: firstly, the word dize (line) is preferred instead of misra (line) and secondly, often is added. Thus, it is explained that the pome lines may begin with both lowercase and uppercase letters. In the orthography guide published in 2012, the expression "poem lines begin with capital letters" (p.13) in again included under the title about capital letter usage. Thus, for seven years, teachers had told students about when to use capital letters that "poem lines often began with capital letters" and after 2012, they 
taught the students that "poem lines began with capital letters". As can be observed, in a period of average 8 to 10 years, guides published included different applications. Another modification example of when to use capital letters is about the addressing in letters and official correspondences. Within the 1996 and 2000 guides, "the first word of addressing begins with capital letter" is included (TLS, 1996: 25 and TLS, 2000: 26). Examples are:

"Dear brother, Beloved friend, and Valued friend".

As can be seen in the addressing examples, the second word begins with lowercase letter. Teachers of Turkish language and literature taught students accordingly and provided similar examples. This rule was modified in the guide published in 2005 as in:

"Addressing begins with capital letters in letters and official correspondence".

The examples of addressing, with second words previously starting in lowercase letters, are provided:

"Dear Brother, Beloved Friend, and Valued Friend" (p.17). No modification about this was included in the orthography guide published in 2012.

Another orthographic difference in capital letters is about the words such as sea, river, lake, mountain, and straits names of types that come second in place names. In the orthographic guides published in 1996 and 2000, the word coming second after place names was stated to begin with lowercase letters; for example, "Marmara denizi, Aral gölü, Sakaryaırmağı, Erciyesdağı (Marmara sea, Aral lake, Sakarya river, and Erciyes mountain)" (TLS, 1996: 26 and TLS, 2000: 27). In the guides published in 2005 and 2012, modification about the second words after place names was included: second words begin with capital letters. Thus, the phrases "Marmara Denizi, Aral Gölü, Sakaryalrmağı, ErciyesDağı (Marmara Sea, Aral Lake, Sakarya River, and Erciyes Mountain)" are written with the second word beginning with capital letter also (TLS, 2005: 18 and TLS, 2012:15).

\section{Modifications about the compound and separate} words: A problematic area in our language is the compound words. There is no consistency about the compound words as to when to write their words separately or to combine them. Therefore, in orthographic guides, compound words have two entries such as "separately written compound words" and "combined compound words". However, spelling of some words differs in various guides published in different years. Therefore, the dispute about the compound words in Turkish still continues. This disputable issue leads to the differences depending on teachers and students, in understanding of writing and spelling teaching. The words with modified spellings in guides published by the Society in 1996 to 2012 are as follows:

The orthographic guides published between 1996 and 2000 state that compound words made up of ev, ocak, and yurt (house, center, and dorm) are to be written separately. For instance: "aşevi, orduevi, sağlıkocağı, yayınevi, sağlıkyurdu, öğrenciyurdu (foodbank, officers' club, health center, publishing house, health house, and student dorm)" (TLS, 1996: 44 and TLS, 2000: 45). However, the guides published in 2005 and 2012 states that the compound words made up of ev (house) are to be combined. The words such as "aşevi, basımevi, öğretmenevi, huzurevi (foodbank, publishing house, teachers' club, and nursing house)" written separately in previous guides are combined now (TLS, 2005: 24 and TLS, 2012: 20). Compound words with Persian "hane (house)" are of those written in different styles. Compound words made up of this particular word are: dershane, postahane, hastahane, pastahane, yemekhane (prep school, post office, hospital, bakery, and dining hall). Recently, the common usage has dropped the syllabus 'ha' in these words: hastane, postane, pastane, dersane. The orthography guides published in 1996 and 2000 stated that the compound words consisting of 'hane' were to be combined and the ' $h$ ' in words such as dershane, eczahane, hastahane, postahane, and pastahane (prep school, pharmacy, hospital, post office and bakery) was not recommended to be dropped (TLS, 1996: 36 and TLS, 2000: 37). Although the syllabus "ha" in dershane, eczahane, hastahane, postahane, and pastahane (prep school, pharmacy, hospital, post office, and bakery) was not recommended to be dropped in orthography guides published in 1996 and 2000, the orthography guide published in 2005 included the words eczahane, hastahane, postahane, and pastahane aseczane, hastane, pastane, andpostane (pharmacy, hospital, post office, and bakery) due to common usage (TLS, 2005: 24). On the other hand, the $16^{\text {th }}$ article of the orthography guide published in 2012 stated under the "combined compound words" heading that "compound words made up of hane, name, zade (house, note, and the son of)" were to be combined and included the following examples: "çayhane, dershane, kahvehane, andyazıhane (tea house, prep school, cofee house, and office)" (TLS, 2012: 20).In the orthography guide published in 2012, Turkish Language Society did not mention the wide spread usage of eczahane, hastahane, postahane, and pastahane aseczane, hastane, pastane, andpostane (pharmacy, hospital, post office, and bakery). TLS conflicted by giving the spelling of these words as eczane, hastane, pastane, andpostanewith its own 1996 and 2000 guides stating that it was not accurate to drop the syllabus "ha" included in eczahane, hastahane, postahane, and pastahane. 
The first example about the differences in spelling compound words consists of compound words made up of ara, dış, öte, and sıra. 1996, 2000, and 2005 orthography guides stated that compound words and terms made of "ara, dış, öte, andsıra" (middle, out, beyond, regular) as suffixes were to be written separately (TLS, 1996: 44 and TLS, 2000: 45 and TLS, 2005: 28). As such, fizikötesi (metaphysical), morötesi (ultraviolet), and kızılötesi (infrared), made up of öte (beyond), were written separately in the guides. However, the 2012 guide included combined compounds fizikötesi and kızılötesi made up of öte without any explanation. Another example for words with different combination is the word büyükşehir (metropolis). This word, written as a separate compound büyükşehir (TLS, 1996: 133 and TLS, 2000: 149) in the 1996 and 2000 guides, was included as combined compound büyükşehir (TLS, 2005: 138 and TLS, 2012: 161) in 2005 and 2012 guides. The third example of different spellings in compound words is the word büyükelçi (ambassador) made up of büyük (great). This word, written as a separate compound büyükelçi (TLS, 1996: 133 and TLS, 2000: 149) in the 1996 and 2000 guides, was included as combined compound büyükelçi (TLS, 2005: 137 and TLS, 2012: 160) in 2005 and 2012 guides. The last example in this section is the word gökkuşağı (rainbow). This word, written as a separate compound gökkuşağı (TLS, 1996: 200 and TLS, 2000: 223) in the 1996 and 2000 guides, was included as combined compound gökkuşağı(TLS, 2005: 224 and TLS, 2012: 261) in 2005 and 2012 guides.

Changes in spelling some words: One of the words that had modified spelling is the word kampüs(campus) originating from French campus. The word whose Turkish correspondent was defined as yerleşke(campus) was included as kampusin 1996 and 2000 ortography guides (TLS, 1996: 243 and TLS, 2000: 272). However, although the word was included as kampus in the guides, it was written as kampüs. Maybe therefore, the TLS gave up kampus and modified the spelling of the word into kampüs in 2005 and 2012 guides (TLS, 2005: 277 and TLS, 2012: 320). In addition to kampüs, differences in the spelling of Kur'an-IKerim (Koran) were also observed. 1996 and 2000 orthography guides included the combined word as Kur'anıkerim (TLS, 1996: 273 and TLS, 2000: 304). Later, the 2005 and 2012 guides included the same word as a noun phrase with the second word beginning with a capital letter: Kur'an-ıKerim (TLS, 2005: 314 and TLS, 2012: 362).

Modifications in abbreviations: Turkish Language Society's orthography guides are observed to have made some modifications in the abbreviations of some words. Adopting a novel abbreviation after so many years of using a former abbreviation confuses people and leads to ambiguous usage. Thus, even if we do not want, more than one abbreviation is available for one word or a concept or an institution. As a result, the orthographic unity is hurt and differences in spelling occur. The chart below includes those concepts and abbreviations modified in orthography guides published between 1996 and 2012. As shown in Table 1.

\section{CONCLUSION AND SUGGESTIONS}

Modifications have been incorporated in the use of capital letters, the orthography of compound words, words originating from foreign words, and the abbreviations. The modification in the compound words is about combining the separately written compound words. The words hastahane, postahane and pastahane made up of the Persian hane were changed into hastane, postane, andpastaneas used commonly. Some abbreviations such as those of yüksekmimar (master architect), yüksekmühendis (certified engineer), and yardımcıdoçent (assistant professor) were modified by taking out a letter as follows:

Yük. Mim. to Y. Mim., Yük.Müh.to Y. Müh., Yard. Doç. To Yrd. Doç. Letters were added on some other abbreviations to modify their spelling as in Araştırmagörevlisi (research assistant), OsmanlıTürkçesi (Ottoman Turkish), Ar. Gör. toArş. Gör, andOsm. toOsm. T.

Punctuation marks were added or taken out from some abbreviations as in the following:

Posta kutusu;P.K., Şirket; Ş. to Ş -punctuation mark taken out - and Saat; satosa., Saniye;sntosn. punctuation mark added.

In addition, some abbreviations given for some concepts previously were re-provided as the abbreviations for other concepts. For instance, the abbreviation $d b$ was provided for dilbilimi (linguistics) in 2005 guide but in 2012 guide, it was provided for dilbilgisi (grammar). Another example for such modification is as follows:

tel was given as the abbreviation for telegram in 2000 guide but it was provided as the abbreviation for telephone in 2005 and 2012 guides.

When the orthography guides are examined, it can be observed that no explanation was offered about these modifications. Thus, educators, writers, journalists, and those who use the written language must be selfinformed about these modifications. Therefore, some self-imposed rules are created. This becomes an ambiguity in the eyes of those teaching and learning Turkish language. Here are some suggested measures for preventing this:

1. Turkish Language Society must announce the 
Table 1. Modified abbreviations are as follows:

\begin{tabular}{|c|c|c|c|c|}
\hline & \multicolumn{4}{|c|}{ Date of Orthography Guides } \\
\hline & 1996 & 2000 & 2005 & 2012 \\
\hline ResearchAssistant (Araştırma Görevlisi) & Ar. Gör. & Arş. Gör. & Arş. Gör. & Arş. Gör. \\
\hline Commander in chief (Başkomutan) & BŞK. & $B s ̧ K$. & - & - \\
\hline Mr. (Bay) & $B$. & $B$. & $B$ & $B$ \\
\hline Botany (Bitki bilimi) & bitb. & bitb. & bitb. & Bit. $b$. \\
\hline Ambassador (Büyükelçi) & B.E. & B.E. & $B E$ & $B E$ \\
\hline Volume (Cilt) & C & C. & C & C \\
\hline Minute (Dakika) & $d k$ & $d k$ & $d k$ & $d k$. \\
\hline Grammar (Dil bilgisi) & $d b l$. & $d b l$. & $d b l$. & $d b$. \\
\hline Linguistics (Dil bilimi) & $d b$. & $d b$. & $d b$. & dil. $b$. \\
\hline WarCollege (Harp Okulu) & H.O. & H.O. & HO & $\mathrm{HO}$ \\
\hline Hospital (Hastane, hastanesi) & Hst. & Hst. & Hst. & $H$ \\
\hline Preparedby (Hazırlayan) & hzl. & hzl. & hzl. & haz. \\
\hline Restricted (Hizmete özel) & Hz. özl. & Hz. özl. & Hz. öz. & Hz. öz. \\
\hline Gendarmery (Jandarma) & $J$. & $J$. & $J$ & $J$ \\
\hline Calory (Kalori) & - & - & cal & kal \\
\hline Land ForcesCommand (Kara Kuvvetleri Kom.) & K.K.K. & K.K.K. & $K K K$ & $K K K$ \\
\hline Latin (Latince) & Lât. & Lât. & Lat. & Lat. \\
\hline Birth of Christ, Current (Milat, miladi) & M. & $M$. & $M$ & $M$ \\
\hline BeforeChrist (Milattan önce) & M.Ö. & M.Ö. & MÖ & MÖ \\
\hline AnnoDomini (Milattan sonra) & M.S. & M.S. & MS & MS \\
\hline Number (Numara) & No. / Nr. / Nu & No. / Nr. / Nu & $\mathrm{Nu}$. & No. \\
\hline OttomanTurkish (Osmanlı Türkçesi) & Osm. & Osm. & Osm. T. & Osm. T. \\
\hline Mail Box (Posta kutusu) & P.K. & P.K. & $P K$ & $P K$ \\
\hline Issue (Sayı) & $S$. & $S$. & $S$ & $s$ \\
\hline Hour (Saat) & sa & sa & sa. & sa. \\
\hline Second (Saniye) & sn & sn & sn. & Sn. \\
\hline Company (Şirket) & Ş. & Ş. & $S$ & $S$ \\
\hline Telephone (Telefon) & tlf. & tlf. & tel. & tel. \\
\hline Telegram (Telgraf) & tlg. & tel. & telg. & telg. \\
\hline Lieutenant (Üsteğmen) & Üstğ. & Üstğ. & Ütğm. & Ütğm. \\
\hline AssistantProfessor (Yardımcı Doçent) & Yard. Doç. & Yard. Doç. & Yrd. Doç. & Yrd. Doç. \\
\hline Master Architect (Yüksek Mimar) & Yük. Mim. & Yük. Mim. & Y. Mim & Y. Mim \\
\hline CertifiedEngineer (Yüksek Mühendis) & Yük. Müh. & Yük. Müh. & Y. Müh. & Y. Müh. \\
\hline Century (Yüzyıl) & $y y$. & yy. & yy. & yy. \\
\hline
\end{tabular}

modifications in orthography sooner for publishing houses, writers, universities and educators.

2. In order to provide unity in writing, the orthography guides prepared by private publishing houses must be audited by the Society. The spelling styles created by writers and publishing houses must be discontinued.

3. Turkish Language Society must include the modifications in orthography guides within a separate section and explain the reason for modifications. Thus, those who teach and learn our language will have the opportunity to understand and explain why the modifications are incorporated.

4. As indicated through the examples pertaining to dilbilimi (linguistics) and dilbilgisi (grammar), no modifi- cations must be incorporated in the commonly used spellings of abbreviations.

5. For accurate use of Turkish language, educational programs must be provided through collaboration with TRT (state TV channel) and radio broadcasters.

\section{Conflict of Interests}

The author(s) have not declared any conflict of interests.

\section{REFERENCES}

Demirel Ö (1999). Türkçe Öğretimi, [Turkish Teaching]. Ankara: PegemA Yayıncılık. 
Göğüş B (1978).Orta Dereceli Okullarımızda Türkçe ve Yazın Eğitimi [Turkish Language and Literature Education in Secondary Schools].Ankara: Gül Yayınevi.

Özbay M (2011). Yazma Eğitimi [Writing Education]. Ankara: Pegem Akademi.

Türk Dil Kurumu (1996). İmlâ Kılavuzu, [Orthography Guide]. Ankara: Türk Tarih Kurumu Basım Evi.

Türk Dil Kurumu (2000).İmlâKılavuzu, [Orthography Guide]. Ankara: Türk Tarih Kurumu Basımevi.
Türk Dil Kurumu (2005).Yazım Kılavuzu, [Orthography Guide]. Ankara: Mesleki Eğitim Merkezi 4. Akşam Sanat Okulu Basımevi.

Türk Dil Kurumu (2012). Yazım Kılavuzu, [Orthography Guide]. Ankara: Türk Dil Kurumu Yayınları.

Türk Dili Kurumu (2005). Türkçe Sözlük, [Turkish Dictinoary]. Ankara: Türk Dil Kurumu Yayınları. 